\title{
Refractory massive pleural effusion in systemic lupus erythematosus treated with talc poudrage
}

\author{
JEFFREY L KAINE \\ From the Division of Rheumatology, Washington University School of Medicine, St Louis, Missouri, USA
}

SUMmARY The case of a 31-year-old black male is presented with recurrent pleural effusions secondary to active SLE. Treatment with corticosteroids, azathioprine, plaquenil, and tetracycline pleural sclerosis was unsuccessful. Disease control was finally achieved by pleural talc poudrage.

Pleural disease is common in systemic lupus erythematosus (SLE). Episodic pleuritis occurs in half of all SLE patients and pleural effusions may be seen in up to one-fourth. They are typically bilateral, clear to light yellow, and small to moderate sized. The fluid is usually exudative, although transudates and frankly haemorrhagic effusions are occasionally seen. Laboratory analyses of the fluid may demonstrate immune complexes, high levels of immunoglobulins, and low complement values. ${ }^{1}$ Pleural thickening with areas of fibrosis and adhesions is common at necropsy. Mononuclear and polymorphonuclear interstitial infiltrates in addition to perivascular fibrinoid necrosis have been observed. Immunofluorescence studies demonstrate focal nuclear staining with immunoglobulin and complement of pleural mesotheiium and/or alveolar lining cells. ${ }^{2-4}$ Interstitial deposits of immunoglobulin and complement are not commonly seen.

Corticosteroid therapy is the mainstay of therapy for symptomatic pleural effusions in SLE. Clinically, patients respond promptly to moderate daily doses of corticosteroids, although occasionally a patient requires several weeks of therapy before radiographic improvement is noted. The purpose of this communication is to report the case of a patient with recurrent massive pleural effusions secondary to active SLE which were unresponsive to corticosteroids, immuinosuppressive therapy, and tetracycline

Accepted for publication 26 July 1984 .

Correspondence to Jeffrey L Kaine, M D, Division of Rheumatology, Department of Medicine, Washington University School of Medicine, 4960 Audubon Avenue, St Louis. MO 63110, USA. pleural sclerosis. The pleural effusions were eventually successfully treated with talc poudrage.

\section{Case report}

A 31-year-old black male was admitted to Barnes Hospital in May 1982 for examination of penile discharge, diffuse arthralgias, and microscopic haematuria. Prior treatment of presumed nongonococcal urethritis had been unsuccessful. While he was in hospital, an extensive urological examination proved unremarkable, but laboratory testing was significant for a mild normochromic normocytic anaemia (haemoglobin $12.8 \mathrm{~g} / \mathrm{dl}$ ) and a serum creatinine of $1.3 \mathrm{mg} / \mathrm{dl}(115 \mu \mathrm{mol} / \mathrm{l})$. Antinuclear antibody (ANA) testing was remarkable for $3+$ homogeneous and rimmed nuclear fluorescence (titre $1: 5120$ ) and $60 \%$ binding of antibodies to native DNA was noted by the Farr assay (normal $<4 \%$ binding). Systemic lupus erythematosus (SLE) was diagnosed, and the patient was started on oral prednisone, $40 \mathrm{mg}$ twice daily.

Over the next five months the SLE remained clinically active. The patient developed episodic pleurisy, arthritis, and bilateral carpal tunnel syndrome. He had a persistently active urinary sediment and $6 \mathrm{~g}$ of proteinuria in a 24-hour urine collection. The serum creatinine was $1.7 \mathrm{mg} / \mathrm{dl}(150$ $\mu \mathrm{mol} / \mathrm{l})$ in October 1982 . Further examination revealed polyclonal cryoglobulins $(78 \mu \mathrm{g} / \mathrm{ml}=78 \mathrm{mg} / \mathrm{l})$, hypocomplementaemia (total haemolytic complement, 32 (normal 150-250) units/ml; C4, 100, (105-305 mg/l); C3, $420 \quad(690-1470 \mathrm{mg} / \mathrm{l})$ and circulating immune complexes detected by the Raji 
cell assay $(5450 \mathrm{mg} / \mathrm{l}$, normal $<500)$. Antibodies to native DNA remained strongly positive with 60 to $90 \%$ binding; high dose prednisone therapy was continued.

In November 1982 the patient developed a moderate sized right pleural effusion. The fluid was drained by thoracentesis and appeared to be a transudate (Table 1). Cultures for bacteria, fungi, and mycobacteria were negative. Cytology was negative. At this time renal function had improved slightly: the serum creatinine was $1.4 \mathrm{mg} / \mathrm{dl}(90$ $\mu \mathrm{mol} / \mathrm{l}$ ) with $1.8 \mathrm{~g}$ protein in a 24-hour urine collection. Prednisone $60 \mathrm{mg} /$ day was continued.

In December 1982 the patient was readmitted to Barnes Hospital with fevers, chills, and shortness of breath. A chest radiograph revealed a massive right pleural effusion, a right subpulmonary effusion, and a small free-flowing left effusion (Fig. 1). Normal cardiac function by physical examination, endocardiography, and radionuclide venticulography was noted. 31 of pleural fluid was drained by thoracocentesis, and analysis again revealed sterile non-inflammatory fluid (Table 1 ). The patient was thought to have active SLE despite high dose corticosteroid therapy. Azathioprine $150 \mathrm{mg} /$ day and hydroxychloroquine $200 \mathrm{mg} /$ day were instituted, while prednisone $60 \mathrm{mg} /$ day was continued.

By March 1983 the right pleural effusion had reaccumulated and the patient was admitted to hospital with identical symptoms. A Cope needle biopsy of the pleura was performed and $4 \mathrm{l}$ of sterile transudative fluid drained by chest tube. Examination showed non-specific acute and chronic inflammation, with fibrous reaction. No granulomas were seen. Cultures and cytologies were again negative. Azathioprine and hydroxychloroquine

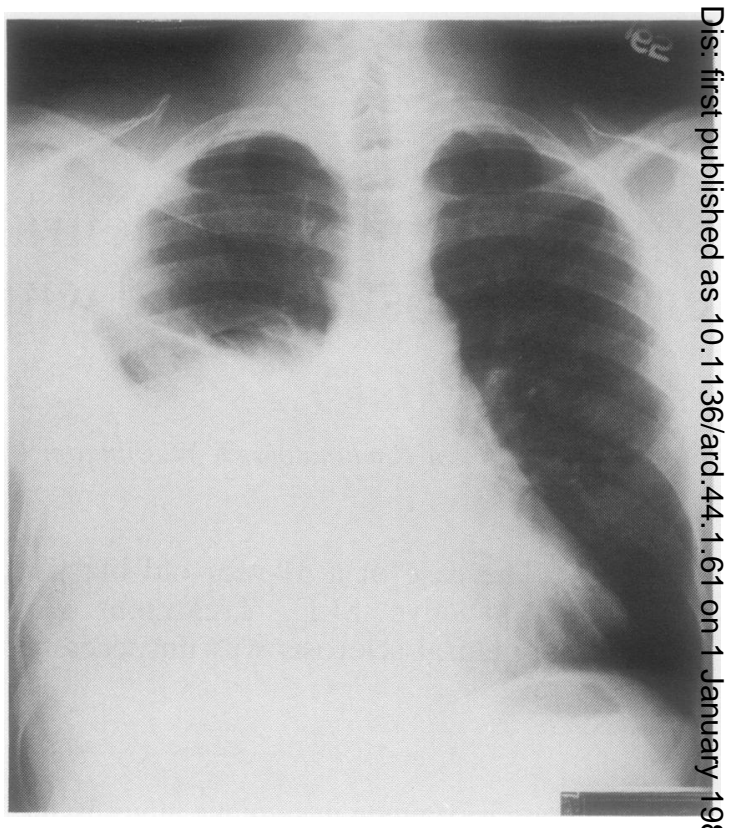

Fig. 1 Refractory pleural effusion in SLE. December 1982.

were discontinued, as they were considered to be্ำ ineffective. Chest tube thoracoscopy was per\% formed, and the pleura was sclerosed with $500 \mathrm{mg}$ op tetracycline. The urine sediment remained active $\overrightarrow{\vec{D}}$ although the serum creatinine had further decreased $B$ to $1.2 \mathrm{mg} / \mathrm{dl}(106 \mu \mathrm{mol} / \mathrm{l})$ by April 1983 .

By June 1983 the patient's prednisone dose had been decreased to $10 \mathrm{mg}$ twice daily without chang in clinical status or renal function. However, $a^{2}$

Table 1 Serial serum and pleural fluid protein determinations, complement values, and anti-DNA antibodies

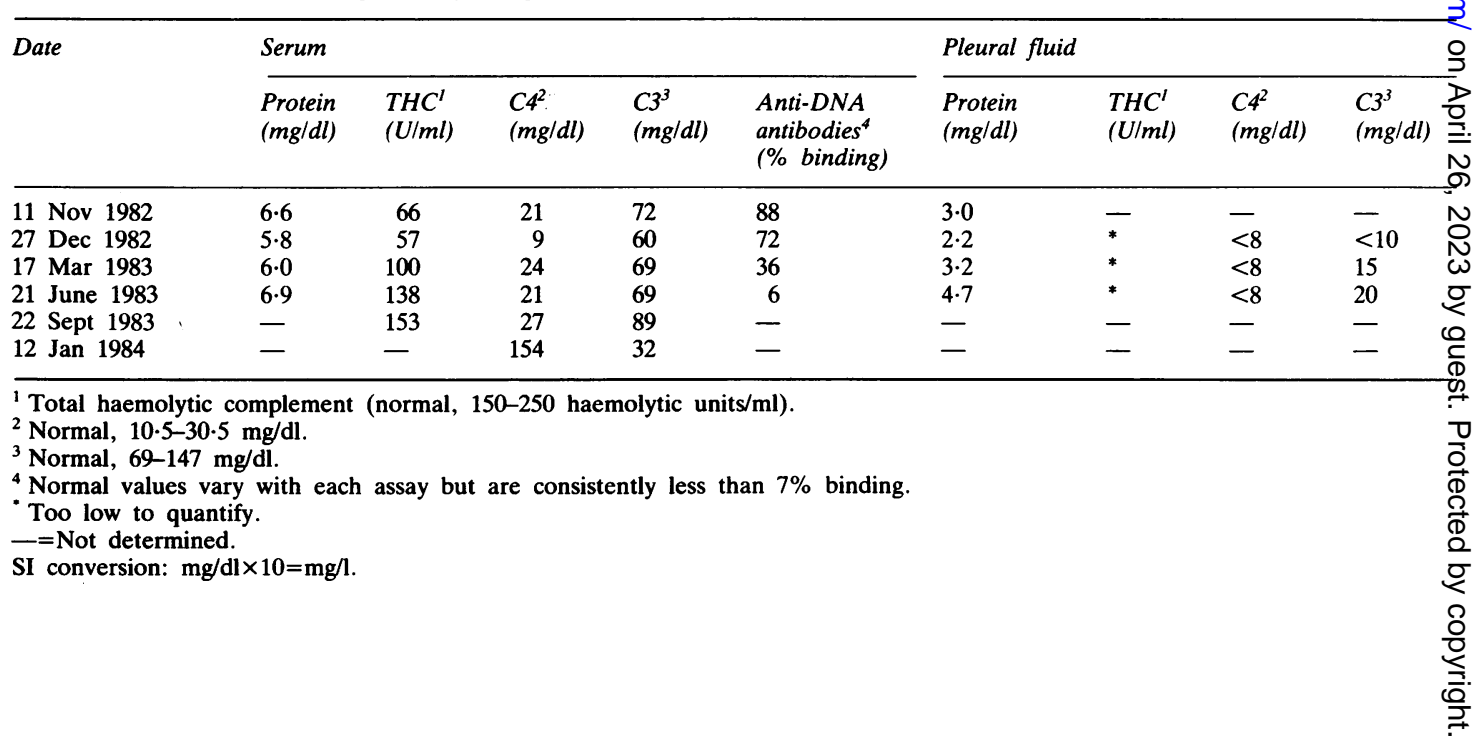




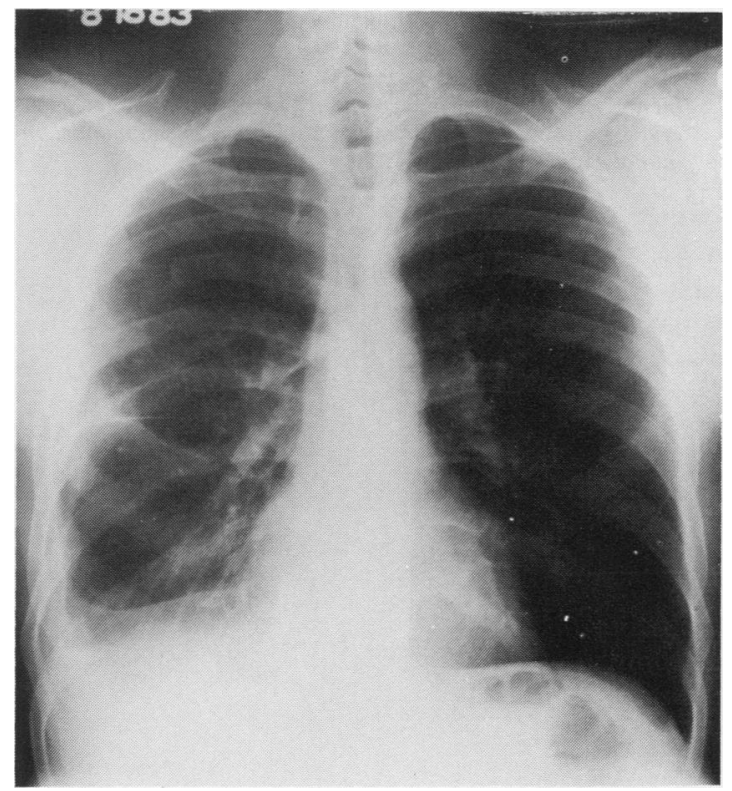

Fig. 2 August 1983, two months after talc poudrage.

massive right pleural effusion was again noted. Chemical evaluation of the pleural fluid gave the same results as in prior studies (Table 1). A CT scan of the pleura failed to show pleural thickening or plaque-like lesions. The patient underwent talc poudrage and has not had any recurrent pulmonary symptoms or evidence of fluid reaccumulation (Fig. 2).

From January 1984 the patient's prednisone dose has been decreased to $10 \mathrm{mg}$ daily. His creatinine is $1.6 \mathrm{mg} / \mathrm{dl}(141 \mu \mathrm{mol} / \mathrm{l})$. Urinalysis shows persistent microscopic haematuria with $1-2 \mathrm{~g}$ of protein per 24-hour urine collection. Serum complement components have become normal (Table 1), though antibodies to native DNA are still slightly raised.

\section{Discussion}

Massive pleural effusions in SLE are rare but described. ${ }^{15}$ They have characteristically responded to glucocorticoid therapy, though several weeks to months may be required for clinical and radiographic resolution. In contrast this patient had massive pleural effusions associated with active SLE which failed to respond to prolonged treatment with $60 \mathrm{mg}$ of prednisone daily for over six months. In addition, it appears unlikely that the brief course of azathioprine and hydroxychloroquine had any effect on this patient's disease course. There seems little doubt that these effusions were secondary to active SLE. Multiple analyses of pleural fluid and serum revealed no evidence of infection, but there was persistent hypocomplementaemia. Clinically and serologically the diagnosis of SLE was well established.

Immune processes have been implicated as probable aetiological factors in the serositis of SLE. ${ }^{4}$ Immune complexes and evidence of complement consumption have been detected in pleural fluid, while pleural immunofluorescence has revealed a nuclear staining against IgG, IgM, and C3. ${ }^{34}$ 6-9 Immunofluorescence was not performed on this patient's pleural biopsy. However, simultaneous comparison of serum and pleural fluid reveals extreme reduction in pleural fluid complement activity, suggesting local complement consumption as opposed to the fluid being an ultrafiltrate of plasma.

Pleural effusion refractory to moderate doses of steroid therapy has not previously been reported to this author's knowledge. However, chronic pleural pain with pleural thickening has been described. Bell and Lawrence ${ }^{9}$ described two patients treated with surgical obliteration of the pleural space and parietal pleurectomy. One patient had been treated with both prednisone and cyclophosphamide without response. ${ }^{10}$ Neither patient, however, had significant pleural effusions.

This case report suggests that massive pleural effusions may occur in SLE and prove rather unresponsive to conventional therapy. In the patient reported the disease was finally controlled by pleural sclerosis with talc poudrage.

The author gratefully acknowledges the suggestions of Dr John Atkinson and the secretarial assistance of Mrs Lorraine Whiteley.

\section{References}

1 Rothfield N F. Cardiopulmonary manifestations. In: Schur P H, ed. The clinical management of systemic lupus erythematosus. New York: Grune and Stratton, 1983; 113-22.

2 Light R W. Pleural disease due to collagen vascular disease. In: Light R W, ed. Pleural diseases. Philadelphia: Lee and Febiger, 1983: 163-71.

3 Pertschuk L P, Moccia L F, Rosen Y, et al. Acute pulmonary complications in systemic lupus erythematosus. Immunofluorescence and light microscopic study. Am J Clin Pathol 1977; 68: 553-7.

4 Inour T, Kanayama Y, Ohe A, et al. Immunopathologic studies of pneumonitis in systemic lupus erythematosus. Ann Intern Med 1979; 91: 30-4.

5 Dubois E L. Lupus erythematosus. Los Angeles: University of Southern California Press, 1976.

6 Halla J T, Schrohenloher R E, Volanakis J E. Immune complexes and other laboratory features of pleural effusions. Ann Intern Med 1980; 92: 748-52.

7 Hunder G G, McDuffie F C, Huston K A, Elveback L R, 


\section{Kaine}

Hepper N R. Pleural fluid complement, complement conversion, and immune complexes in immunologic and nonimmunologic diseases. J Lab Clin Med 1977; 90: 971-80.

8 Andrews B S. The role of immune complexes in the pathogenesis of pleural effusions. Am Rev Respir Dis 1981; 124: 115-20.

9 Bell R, Lawrence D S. Chronic pleurisy in systemic lupus erythematosus treated with pleurectomy. Br J Dis Chest 1979 के.
79: $314-6$.

10 Glovsky M M, Louie J S, Pitts W H, Alenty A. Reduction of pleural fluid complement activity in patients with systemic lupus erythematosus and rheumatoid arthritis. Clin Immunol Im munopathol 1976; 6: 31-41.

席:

